\title{
New Brightener for Zn-Fe Alloy Plating from Sulphate Bath
}

\author{
B. M. Praveen ${ }^{1}$ and T. V. Venkatesha ${ }^{2}$ \\ ${ }^{1}$ Department of Chemistry, Srinivas School of Engineering, Mukka Mangalore 575 021, India \\ ${ }^{2}$ Department of PG Studies and Research in Chemistry, School of Chemical Sciences, Kuvempu University, \\ Shankaraghatta 577 451, India \\ Correspondence should be addressed to T. V. Venkatesha, drtvvenkatesha@yahoo.co.uk
}

Received 14 May 2011; Revised 1 June 2011; Accepted 3 June 2011

Academic Editor: Sheng S. Zhang

Copyright ( $) 2011$ B. M. Praveen and T. V. Venkatesha. This is an open access article distributed under the Creative Commons Attribution License, which permits unrestricted use, distribution, and reproduction in any medium, provided the original work is properly cited.

\begin{abstract}
$\mathrm{Zn}$-Fe alloy electrodeposition was carried out in the presence of condensation product 2-\{[(1E)-(3,4-dimethoxyphenyl)methylidene]amino -3-hydroxypropanoic acid formed between veratraldehyde and serine in acid sulphate bath. Hull cell was used for optimizing the operating parameters and bath constituents. During deposition, the potential was shifted towards cathodic direction in the presence of addition agents and brightener. The polarization studies show that deposition taking place in basic bath and optimum bath was 1.08 and $1.15 \mathrm{~V}$, respectively. Current efficiency and throwing power were reached around $85 \%$ and $26 \%$, respectively. The SEM images of bright deposit indicated its fine-grained nature and appreciable reduction in the grain size. XRD studies have showed that the grain size of the deposit generated from optimum bath was $16 \mathrm{~nm}$. UV-visible spectroscopic studies confirm the formation of complex between metal ion and brightener.
\end{abstract}

\section{Introduction}

Zinc and zinc alloys are widely used to electroplate steel sheet to provide corrosion resistance, mainly in the automobile industries. The corrosion resistance of pure zinc coating over steel is not satisfactory and not acceptable under severe atmospheric conditions. Several methods and materials, such as different organic paints and zinc alloys, are being examined for improved corrosion resistance and better economical means of protection of steel sheets for longer times under severe atmospheric conditions [1-3]. Electrodeposited Zn with Fe group metals have been shown to significantly extend the corrosion protection of steel with respect to $\mathrm{Zn}$ coatings. The highest corrosion resistance is achieved when $\mathrm{Co}$ or Fe in the alloy is less than $1 \mathrm{wt} \%$ and the amount of $\mathrm{Ni}$ is within 9$15 \mathrm{wt} \%$ [4-6]. Alloying with Zn confers sufficient corrosion resistance to steel that nowadays is a common procedure for most industries, particularly the automotive industry. They have numerous important industrial applications in the chemical and galvanic process of automobile and aerospace industries. In addition, $\mathrm{Zn}$-Fe alloy coatings with high iron content can serve as an effective undercoat for paints [7].

In order to get the good metallurgical properties of the coatings, grain size of the coating should be uniform, smaller, and bright. So some organic compounds are required for getting the bright deposit. Exact mechanism of the brighteners role is not established. So generally, industrialists used large number of organic compounds to get bright deposit in a single bath. It produces more and more pollutants to the environment [8].

In the present study efforts have been made to develop the brightener for the electrodeposition of $\mathrm{Zn}-\mathrm{Fe}$ alloy deposit over wide current density range from sulphate bath. The deposit is obtained by Hull cell experiments in presence of newly synthesized condensation product $2-\{[(1 E)$ (3,4-dimethoxyphenyl)methylidene]amino -3-hydroxy-

propanoic acid formed between veratraldehyde and serine based on the results of Hull cell experiments. The bath constituents concentration and operating conditions are optimized. Basic studies such as polarization studies, current efficiency, and throwing power of the bath are reported.

\section{Experimental}

All the chemicals used were of AR grade. In the preparation of solutions distilled water was used. All experiments were conducted at $303 \pm 1 \mathrm{~K}$. A Hull cell of $267 \mathrm{~mL}$ capacity was used to optimize the bath constituents. The Hull cell 
TABLE 1: Basic bath composition and operating conditions.

\begin{tabular}{lcc}
\hline Constituents & Conc. $\left(\mathrm{gL}^{-1}\right)$ & Operating conditions \\
\hline $\mathrm{ZnSO}_{4} \cdot 7 \mathrm{H}_{2} \mathrm{O}$ & 140 & Anode: zinc metal $(99.99 \%)$ \\
$\mathrm{FeSO}_{4} \cdot 7 \mathrm{H}_{2} \mathrm{O}$ & 8 & Cathode: mild steel \\
$\mathrm{Na}_{2} \mathrm{SO}_{4}$ & 30 & Temperature: $298 \mathrm{~K}$ \\
$\mathrm{H}_{3} \mathrm{BO}_{3}$ & 8 & Cell current: $1 \mathrm{~A}$ \\
$\mathrm{CTAB}$ & 1 &
\end{tabular}

experiments were carried out without agitation of the bath solution (Table 1). The $\mathrm{pH}$ of the solution was adjusted with $10 \% \mathrm{H}_{2} \mathrm{SO}_{4}$ or sodium bicarbonate solution. Zinc plate of 99.99\% was used as anode. The anode was activated each time by immersing in $10 \% \mathrm{HCl}$ for few seconds followed by water wash.

The condensation product $2-\{[(1 E)-(3,4$-dimethoxyphenyl)methylidene]amino -3-hydroxypropanoic acid was prepared using veratraldehyde $\left(\mathrm{C}_{9} \mathrm{H}_{10} \mathrm{O}_{3}\right)$ (AR grade, SD fine chemicals, Mumbai, India), and Serine $\mathrm{C}_{3} \mathrm{H}_{7} \mathrm{NO}_{3}$ (AR grade, SD fine chemicals, Mumbai, India) was added to the bath solution. Condensation product was synthesized by dissolving $0.39 \mathrm{~g}$ of veratraldehyde in $25 \mathrm{~mL}$ of ethanol, and the resultant solution was stirred for $2 \mathrm{~h}$ with catalytic amount of glacial acetic acid. To this solution $0.25 \mathrm{~g}$ of serine in acetic acid was added with stirring. The resultant mixture was stirred with heating on hot plate for about 6 hours. The completion of the reaction was tested by TLC. The formed product was diluted to $50 \mathrm{~mL}$, and it was used as a brightener. The scheme of the reaction was shown in Figure 1.

Mild steel plates (cathodes-AISI-1079) of standard size mechanically polished to obtain a smooth surface and degreased by exposing to the vapors of trichloroethylene taken in a degreaser plant. The scales and dust of the steel plates were removed by dipping in $10 \% \mathrm{HCl}$ solution. After this the steel plate was washed with water and used for experiment as such.

In order to know the influence of addition agents a known specified amount was added to the bath solution (Table 1). The resulted bath solution was stirred for $30 \mathrm{mi}$ nutes and then subjected to Hull cell experiments. After the Hull cell experiment the plate was removed from the solution and given bright dip in $1 \%$ nitric acid for 5 to 10 seconds followed by water wash. The nature and appearance of zinc plating were carefully studied and recorded through the Hull cell codes (Figure 2).

To test the performance of coating a large number of steel plates were coated with $\mathrm{Zn}$-Fe deposit from the optimized solution in a rectangular methacrylate cell of capacity 2.5 liter. Polished, degreased, and electrocleaned steel plates of $3 \times 4 \mathrm{~cm}^{2}$ area were used. These $\mathrm{Zn}$-Fe-plated steel plates were used to determine the different properties and corrosion resistance of the deposit. Measurement of these properties was done in triplicate. Standard experimental procedures were adopted for the measurement of adherence, ductility, hardness, and so forth. In all the above measurement the average thickness of the deposit was $10 \mu \mathrm{m}$.
The corrosion resistance and service life of coating were assessed by salt spray test. Few steel plates after deposition were given bright dip followed by passivation in a solution containing $200 \mathrm{gL}^{-1}$ of sodium dichromate and $2 \mathrm{mLL}^{-1}$ of sulphuric acid at $303 \mathrm{~K}$. The chromated samples were dried for 24 hours in a clean atmosphere before placing them in a salt spray chamber. The test was performed as per ASTM standard method B-117 using 5\% neutral $\mathrm{NaCl}$ solution (308 K).

A three-comportment electrochemical cell was used for the polarization studies. The area of zinc anode was $2 \mathrm{~cm}^{2}$. The cathode was mild steel, and the area exposed was $2 \mathrm{~cm}^{2}$. The cathode potential was recorded, galvanostatically, with respect to saturated calomel electrode at different current densities. For current efficiency and throwing power measurement, the Haring and Blum cell was used. For throwing power measurement the current distribution ratio between anode and cathode was $1: 5$. For determining consumption of brightener repeated plating was carried out using bath solution present in rectangular cell of $2.5 \mathrm{~L}$ capacity. In all these experiments, the $\mathrm{pH}$ of the solution before and after the experiments and the cell voltage were noted. IR spectrum of the scraped deposit was recorded using Shimadzu FTIR 8400 instrument and was used to study the inclusion of addition agents. SEM photomicrographs were taken to ascertain the nature of deposit in presence of addition agents.

$\mathrm{X}$-ray diffraction studies of the zinc deposits were carried out by using Philips TW 3710 X-ray recorder. Crystallographic texture and approximate average grain size of the bright and dull deposit were calculated. The grain sizes of the coating were calculated using Scherrer's equation.

The UV-vis spectrum of the basic bath and optimum bath was recorded with a Shimadzu UV-1650PC spectrophotometer, using $1 \mathrm{~cm}$ quartz cell. The wavelength was from $200 \mathrm{~nm}$ to $400 \mathrm{~nm}$.

\section{Results and Discussion}

\subsection{Hull Cell Studies}

3.1.1. Effect of Condensation Product. Deposits obtained from Hull cell experiments with the basic bath solution (Table 1) were coarse dull deposit between the current density range of 0.5 and $3.5 \mathrm{Adm}^{-2}$ at $1 \mathrm{~A}$ cell current. To improve the nature of deposit condensation product $2-\{[(1 E)$ (3,4-dimethoxyphenyl)methylidene] amino $\}$-3-hydroxypropanoic acid formed between veratraldehyde and Serine was added to the bath solution.

At low concentration of condensation product the deposit was semibright between the current density ranges of 1.0 to $7.0 \mathrm{Adm}^{-2}$. At low current density dull and at high current density burnt deposits were obtained. With increase in the concentration of condensation product, the nature of the deposit improved and at a concentration of $24 \mathrm{mLL}^{-1}$ the Hull cell panels were bright between the current density range of 1 and $7 \mathrm{Adm}^{-2}$. Further increase in the concentration of condensation product up to $36 \mathrm{mLL}^{-1}$ does not affect the nature of the deposit, but above $36 \mathrm{mLL}^{-1}$ gave 


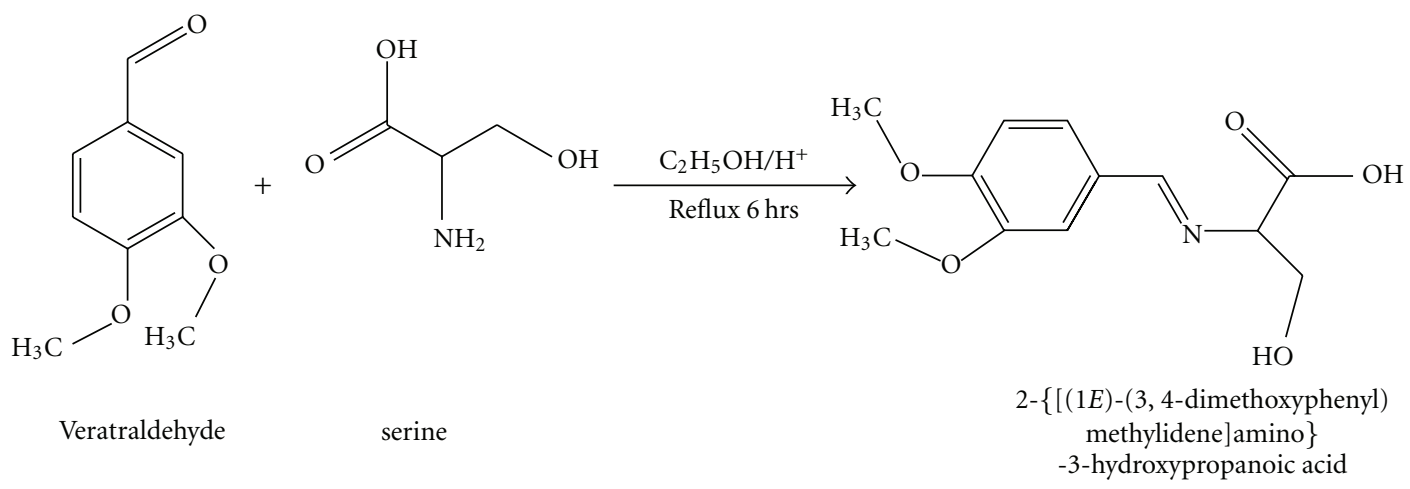

FIgURE 1: Reaction scheme.

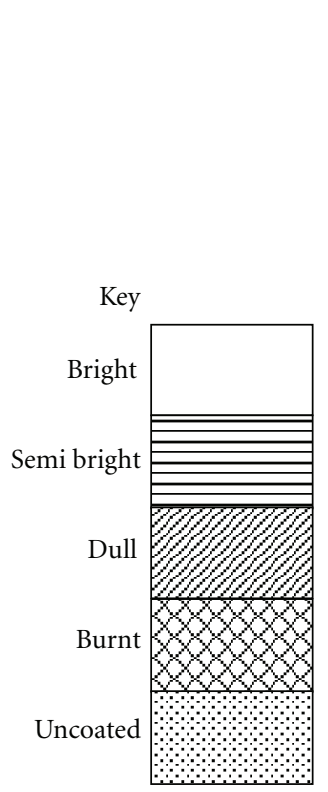

(a)

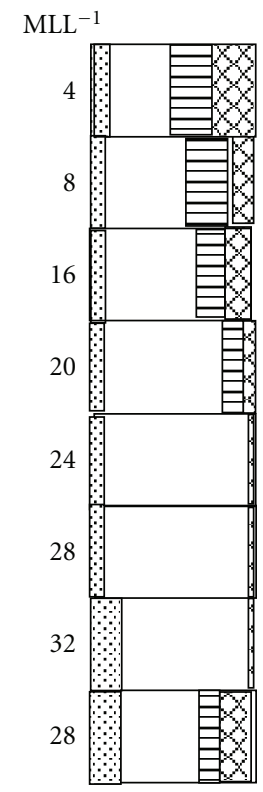

(b)

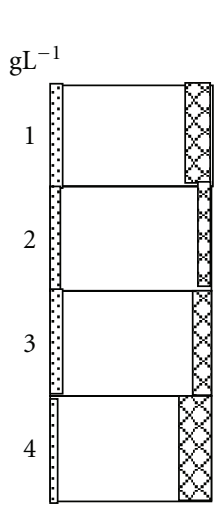

(c)

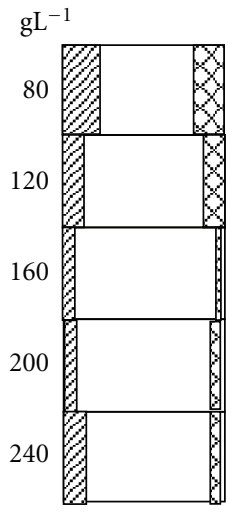

(d)

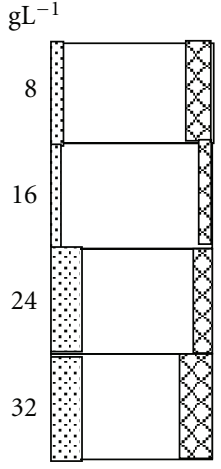

(e)

$\mathrm{pH}$

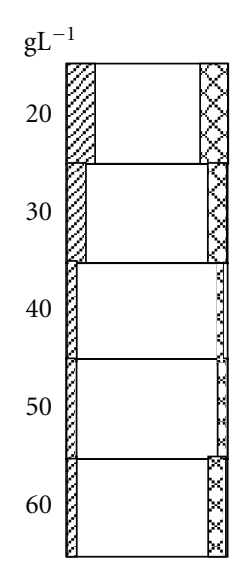

(f)

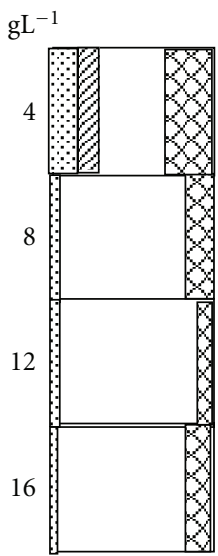

(g)

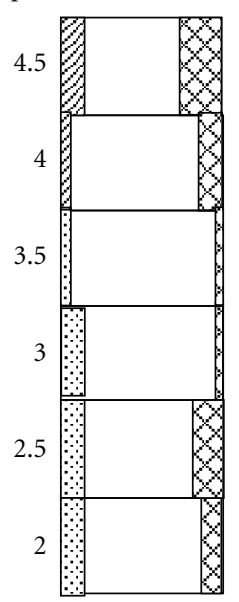

(h)

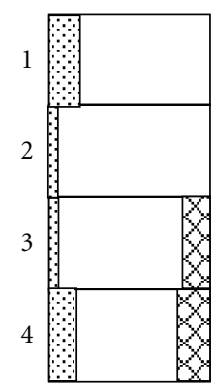

(i)

Figure 2: (a) Key, (b) brightener, (c) CTAB, (d) $\mathrm{ZnSO}_{4}$, (e) $\mathrm{FeSO}_{4} \cdot 7 \mathrm{H}_{2} \mathrm{O}$ (f) $\mathrm{Na}_{2} \mathrm{SO}_{4}$ (g) $\mathrm{H}_{3} \mathrm{BO}_{3}$ (h) pH, and (i) current density. 
dull deposit in the high current density region. Based on the above observation the concentration of the condensation product was kept at $24 \mathrm{mLL}^{-1}$ as optimum. The Hull cell patterns are shown in Figure 2(b).

3.1.2. Effect of $C T A B$. The concentration of CTAB was varied from 1 to $4 \mathrm{gL}^{-1}$, keeping the concentration of zinc sulphate at $140 \mathrm{gL}^{-1}$, Ferrous sulphate at $8 \mathrm{gL}^{1}$, sodium sulphate at $30 \mathrm{gL}^{-1}$, boric acid at $8 \mathrm{gL}^{-1}$, and condensation product at $24 \mathrm{mLL}^{-1}$. At low concentration of CTAB the nature of the deposit was bright in the current density range of 1$7 \mathrm{Adm}^{-2}$ but above $7 \mathrm{Adm}^{-2}$ burnt deposit was observed. So concentration of CTAB was varied from 1 to $4 \mathrm{gL}^{-1}$. When the concentration of CTAB is $2 \mathrm{gL}^{-1}$, it gives bright deposit from 0.5 to $8.0 \mathrm{Adm}^{-2}$ and above this concentration semibright region increased so CTAB was fixed at $2 \mathrm{gL}^{-1}$ as optimum concentration. The Hull cell patterns are shown in Figure 2(c).

3.1.3. Effect of Zinc Sulphate. To know the effect of zinc metal ion concentration, the zinc sulphate concentration was varied from $80 \mathrm{gL}^{-1}$ to $240 \mathrm{gL}^{-1}$, keeping the concentration of sodium sulphate at $30 \mathrm{gL}^{-1}$, boric acid at $8 \mathrm{gL}^{-1}$, ferrous sulphate $8 \mathrm{gL}^{-1}$, and CTAB at $2 \mathrm{gL}^{-1}$. At lower concentration of zinc sulphate, bright deposits were observed in the current density range between 1 to $6 \mathrm{Adm}^{-2}$. At low current density range $\left(<1.0 \mathrm{Adm}^{-2}\right)$ a thin deposit and above $6 \mathrm{Adm}^{-2}$ burnt deposit was observed. It was noticed that the Hull cell patterns were almost free from burnt deposit when the concentration of zinc sulphate reached $160 \mathrm{gL}^{-1}$. At still higher concentrations ( $>200 \mathrm{gL}^{-1}$ ) there was no appreciable change in the deposit nature. Influence of zinc sulphate on Hull cell patterns is shown in Figure 2(d). The concentration of zinc sulphate was fixed at $160 \mathrm{gL}^{-1}$ as optimum.

3.1.4. Effect of Ferrous Sulphate. To find out the effect of iron metal ion concentration, ferrous sulphate was varied from 8 to $32 \mathrm{gL}^{-1}$ by keeping the concentration of condensation product at $24 \mathrm{mLL}^{-1}$, zinc sulphate at $160 \mathrm{gL}^{-1}$, sodium sulphate at $30 \mathrm{gL}^{-1}$, boric acid at $8 \mathrm{gL}^{-1}$, and CTAB at $2 \mathrm{gL}^{-1}$. At lower concentration of ferrous sulphate $\left(<4 \mathrm{gL}^{-1}\right)$ the bright deposit was observed in the current density range between 1.0 to $6 \mathrm{Adm}^{-2}$. With increase in the concentration of ferrous sulphate (upto $16 \mathrm{gL}^{-1}$ ) the bright deposit was extended in the current density range of 0.5 to $8 \mathrm{Adm}^{-2}$; with further increase in the ferrous sulphate concentration in the bath solution, a reduction in the bright current density range and increase in the uncoated and burnt area was observed. Based on the observation the concentration of ferrous sulphate in the bath solution was fixed at $16 \mathrm{gL}^{-1}$ as optimum. The effect of ferrous sulphate concentration on deposit nature is shown in Figure 2(e).

3.1.5. Effect of Sodium Sulphate. Sodium sulphate was added to increase the conductance of the bath solution. The concentration of sodium sulphate was varied from 20 to $60 \mathrm{gL}^{-1}$ by keeping concentration of condensation product at $24 \mathrm{mLL}^{-1}$, zinc sulphate at $160 \mathrm{gL}^{-1}$, ferrous sulphate at $16 \mathrm{gL}^{-1}$, boric acid at $8 \mathrm{gL}^{-1}$, and CTAB at $2 \mathrm{gL}^{-1}$. At lower concentration of sodium sulphate $\left(<30 \mathrm{gL}^{-1}\right)$, the Hull cell panels showed burnt deposit at higher current density region and uncoated at low current density region. The burnt and uncoated regions were found to be reduced when the concentration of sodium sulphate was $40 \mathrm{gL}^{-1}$. Further increase of sodium sulphate concentration does not have any effect on the nature of the deposit. Based on the above observation the concentration of sodium sulphate was fixed at $40 \mathrm{gL}^{-1}$ as optimum. The effect of sodium sulphate concentration on deposit nature is shown in Figure 2(f).

3.1.6. Effect of Boric Acid. The aim of addition of boric acid to the electroplating bath was to control variation of $\mathrm{H}^{+}$ion concentration in the bath solution. To see the optimum concentration of boric acid, the concentration was varied from 4 to $16 \mathrm{gL}^{-1}$ by keeping the concentration of other addition agents at optimum concentrations. At lower concentration of boric acid $\left(<8 \mathrm{gL}^{-1}\right)$, the deposit was bright over the current density range between 2 and $6 \mathrm{Adm}^{-2}$. The bright area was extended between the current density range $0.5-8.0 \mathrm{Adm}^{-2}$ when the concentration of boric acid was $12 \mathrm{gL}^{-1}$. Higher concentration of boric acid will not cause any effect on the Hull cell pattern. So the concentration of boric acid was fixed at $12 \mathrm{gL}^{-1}$. The effect of boric acid on deposit nature is shown in Figure $2(\mathrm{~g})$.

3.1.7. Effect of $p H$. In order to study the effect of $\mathrm{pH}$ on deposit nature, the $\mathrm{pH}$ of the bath solution was varied from 2 to 5 . At low $\mathrm{pH}$ between 2 to 2.5 , the hull cell pattern showed burnt deposit at high current density region and uncoated area on low current density region. At pH 3.5 satisfactory results were obtained and the specimens were completely free from burnt and uncoated regions. With increase in $\mathrm{pH}$ above 4 the deposit becomes dull and cloudy. By these observations the $\mathrm{pH}$ of the solution was fixed at 3.5 in the bath solution. The effect of $\mathrm{pH}$ on the deposit nature is shown in Figure 2(h).

3.1.8. Effect of Cell Current. The Hull cell experiments were carried out at different cell currents (1-4A) using optimized bath solution. It was found that, at a cell current of $1 \mathrm{~A}$, the deposit was bright in the current density range $2-4 \mathrm{Adm}^{-2}$ but uncoated region was observed in the region less than the $2 \mathrm{Adm}^{-2}$. At a cell current of $2 \mathrm{~A}$ uncoated area was minimized and gives the bright deposit from $0.5 \mathrm{Adm}^{-2}$ to $8 \mathrm{Adm}^{-2}$. In $3 \mathrm{~A}$ and $4 \mathrm{~A}$ the bright current density area was reduced and the high current density region was covered with burnt deposit. From these observations it was found that the optimized bath produced bright deposition in the current density range of 1-7 $\mathrm{Adm}^{-2}$. The Hull cell patterns are shown in Figure 2(i).

3.2. Current Efficiency and Throwing Power. Current efficiency and throwing power were measured at different current densities using optimized bath solution (Table 2). At $1 \mathrm{Adm}^{-2}$, the current efficiency was found to be $84 \%$ (Table 3). At a current density of $2 \mathrm{Adm}^{-2}$, the current 
TABle 2: Optimum bath composition and conditions.

\begin{tabular}{lcl}
\hline Bath constituents & $\begin{array}{l}\text { Concentration } \\
\left( \pm 5 \% \text { in } \mathrm{gL}^{-1}\right)\end{array}$ & Operating conditions \\
\hline $\mathrm{ZnSO}_{4} \cdot 7 \mathrm{H}_{2} \mathrm{OgL}^{-1}$ & 160 & $\begin{array}{l}\text { Anode: zinc metal } \\
(99.99 \%)\end{array}$ \\
$\mathrm{FeSO}_{4} \cdot 7 \mathrm{H}_{2} \mathrm{OgL}^{-1}$ & 16 & $\begin{array}{l}\text { Cathode: mild steel } \\
\text { Temperature: }\end{array}$ \\
$\mathrm{Na}_{2} \mathrm{SO}_{4} \mathrm{gL}^{-1}$ & 40 & $\begin{array}{l}293-303 \mathrm{~K} \\
\text { Bright current density } \\
\text { range: } 0.5-8 \text { Adm }\end{array}$ \\
$\mathrm{H}_{3} \mathrm{BO}_{3} \mathrm{gL}^{-1}$ & 12 & $\begin{array}{l}\text { Agitation: air } \\
\text { pH }=3.5\end{array}$ \\
$\mathrm{CTAB} \mathrm{gL}^{-1}$ & 2 & \\
\end{tabular}

TABLE 3: Current efficiency and throwing power at different current densities.

\begin{tabular}{lcc}
\hline $\begin{array}{l}\text { Current density } \\
\left(\mathrm{Adm}^{-2}\right)\end{array}$ & $\begin{array}{c}\text { Current efficiency } \\
(\%)\end{array}$ & $\begin{array}{c}\text { Throwing power } \\
(\%)\end{array}$ \\
\hline 1 & 84.0 & 24.0 \\
2 & 84.8 & 24.6 \\
3 & 82.6 & 25.4 \\
4 & 83.0 & 26.0 \\
5 & 82.2 & 23.6 \\
\hline
\end{tabular}

efficiency was found to be $84.8 \%$. With increase in the current density above $3 \mathrm{Adm}^{-2}$, the current efficiency was found to be decreased, and at $5 \mathrm{Adm}^{-2}$ it was $82.2 \%$. The throwing power of the bath solution was measured by Haring and Blum cell and it is in the range $23-26 \%$.

3.3. Polarization Study. The potential of steel cathode was measured galvanostatically with respect to saturated calomel electrode, at different current densities using the bath solution with and without addition agents. The variation of cathode potential with current density is shown in Figure 3. In basic bath reduction of metal ions takes place at 1.08 volts and after applying this much of voltage current is raised suddenly and same trend was observed in presence of CTAB but not such type of observations were found in presence of brightener. It indicates it polarizes at more negative potential so it requires high potential for reduction. It reveals that in presence of addition agent slow reduction takes place so uniform crystals were obtained in presence of brightener.

3.4. Corrosion Resistance. Mild steel panels of $2 \times 2 \mathrm{~cm}^{2}$ area were polished, degreased, and treated with $10 \%$ hydrochloric acid followed by water wash. These plates were plated with zinc-iron alloy from optimum plating bath at different current densities (Table 2). In presence of addition agents, the deposits were pore-free in nature above a thickness of $10 \mu \mathrm{m}$ as indicated by ferroxyl test. In absence of addition agents, the coating was highly porous even at a thickness of $20 \mu \mathrm{m}$.

The corrosion resistance of $\mathrm{Zn}$-Fe alloy-plated steel plates was tested by salt spray method (ASTM B-117). Mild steel plates $\left(5 \times 5 \mathrm{~cm}^{2}\right)$ were coated with Zn-Fe alloy from the optimum bath solution. These plates were given bright dip in

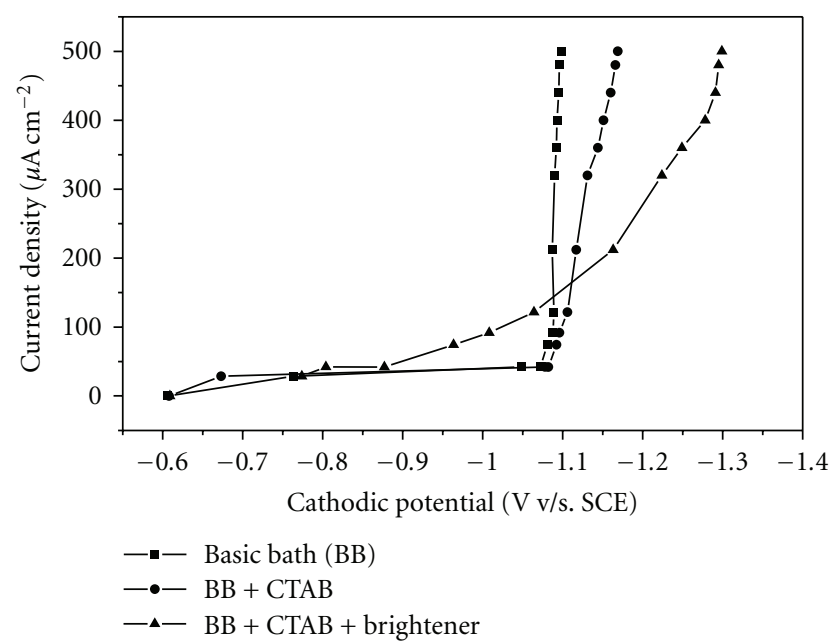

FIgURE 3: cathodic polarization curves in presence of different addition agents.

$1 \%$ nitric acid followed by chromate passivation. Before subjecting to the salt spray test, the plates were kept in a clean and dry atmosphere for $24 \mathrm{~h}$. Even after $120 \mathrm{~h}$ of salt spray test no white rust was observed on the specimens. This indicated good corrosion resistance of the deposit.

3.5. Metallurgical Properties. An important property of an electrodeposit is its adhesion to the base metal. Usually, $\mathrm{Zn}$-Fe deposits on mild steel have very good adhesion. To measure adherence the $\mathrm{Zn}$-Fe deposits of 10-20 $\mu \mathrm{m}$ thickness were obtained under optimum conditions of plating bath on mild steel plates $\left(1 \times 10 \mathrm{~cm}^{2}\right)$. These plated specimens were subjected to bend test through $90^{\circ}$ and finally through $180^{\circ}$. Even after $180^{\circ}$ bending no crack or peel-off was observed in the deposit. This reveals good adhesion of zinc deposit to the substrate. The more useful method for measuring microhardness involves making an indentation with an indenter of specified geometry under a specified load. The length of indentation is expressed in Vickers hardness number (VHN). Zn-Fe alloy was electroplated on mild steel panels up to a thickness of $20 \mu \mathrm{m}$, and a load of $50 \mathrm{~g}$ was employed. The microhardness of $\mathrm{Zn}-\mathrm{Fe}$ alloy was found to be 130 .

3.6. Surface Morphology and IR Studies. SEM photomicrographs of Zn-Fe alloy deposit obtained from bath solution with and with out addition agents are shown in Figure 4. The larger grain size was observed in case of basic bath (Figure $4(\mathrm{a})$ ) but in presence of CTAB reduction in grain size was observed (Figure 4(b)). In presence of condensation product grain size was completely reduced, and uniform crystals were observed so it gives bright deposit (Figure 4(c)). Figure 4(d) SEM shows the passivated bath.

The IR spectrum of the scrapped deposit obtained from the optimized bath (Figure 5) was used to determine the inclusion of an organic compound in the deposit. The IR spectrum contains peak at $1580 \mathrm{~cm}^{-1}$ which corresponds to $>\mathrm{C}=\mathrm{N}$ stretching. The absorption peaks in the IR spectrum 


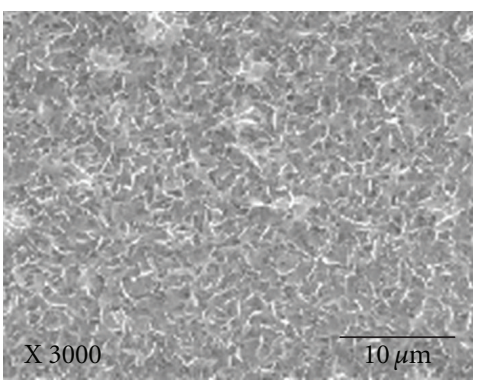

(a)

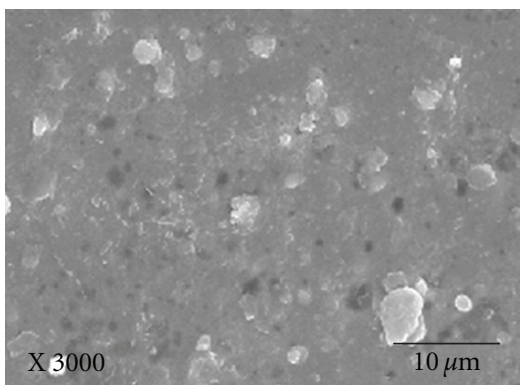

(c)

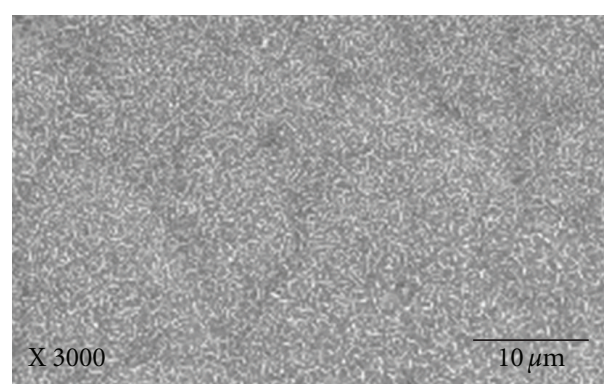

(b)

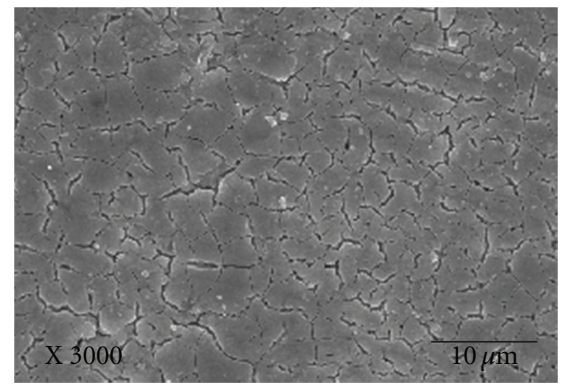

(d)

FigurE 4: SEM photomicrographs of Basic bath (BB) (a), BB + CTAB (b), optimized bath (c), passivated bath (d).

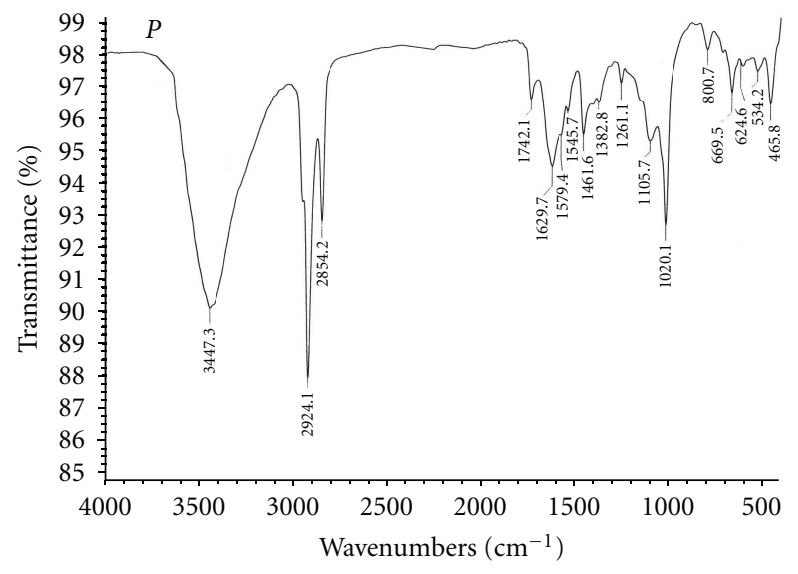

FIGURE 5: FT IR spectrum of scrapped compound.

revealed the inclusion of addition agent in the deposit during electrodeposition.

3.7. X-Ray Diffraction Studies. The crystal structures of the zinc coatings with and without additive were investigated by using X-ray diffraction technique. The $2 \theta$ values of the sample match well with the standard JCPDS file (Figure 6) and show X-ray diffraction patterns of dull and bright zinc deposit, respectively. Crystalline size was determined from the full wave at half maximum (FWHM) of the X-ray peaks present on the diffractogram. The intensity of X-ray patterns of the bright deposit was less and more broader but in dull deposit inverse type results were observed. This intensity informed the good refinement in case of bright deposit. The average grain size of crystallites from dull deposit was $34 \mathrm{~nm}$, and it was $16 \mathrm{~nm}$ for bright deposit.

3.8. UV-Visible Spectral Studies. UV-visible spectra was shown in Figure 7. The absorption maximum of the basic bath appeared at $296 \mathrm{~nm}$. In presence of CTAB also same trend is continued. But in presence of brightener absorption maximum was shifted to the $307 \mathrm{~nm}$. This bathochromic shift indicates the formation of complex of brightener with metal ion. Complex compounds and ions in a plating bath serve two purposes. Firstly, they make it possible to maintain a high metal ion concentration but a low free metal ion concentration. The complex ions of the complex compound serve as a buffer and continuously supply the simple ions necessary for discharge at the cathode. A low metal ion concentration enables the production of deposits with smaller grains and improves the throwing power. Secondly, complex formation enables to enhance appreciably the solubility of sparingly soluble salts.

3.9. Consumption of Brightener. To know the amount of addition agents consumed during plating the bath, $2.5 \mathrm{~L}$ of bath solution was taken and plating was carried out at different current densities. The total number of coulombs passed to the bath solution was recorded at the time when the bath just started to give semibright deposit. The bath solution after use was subjected to Hull cell test by adding different amounts of condensation product. The concentration of condensation product, at which once again bright deposit was obtained, was determined. The amount of condensation product consumed for 1000 amps-h was $10 \mathrm{mLL}^{-1}$. 


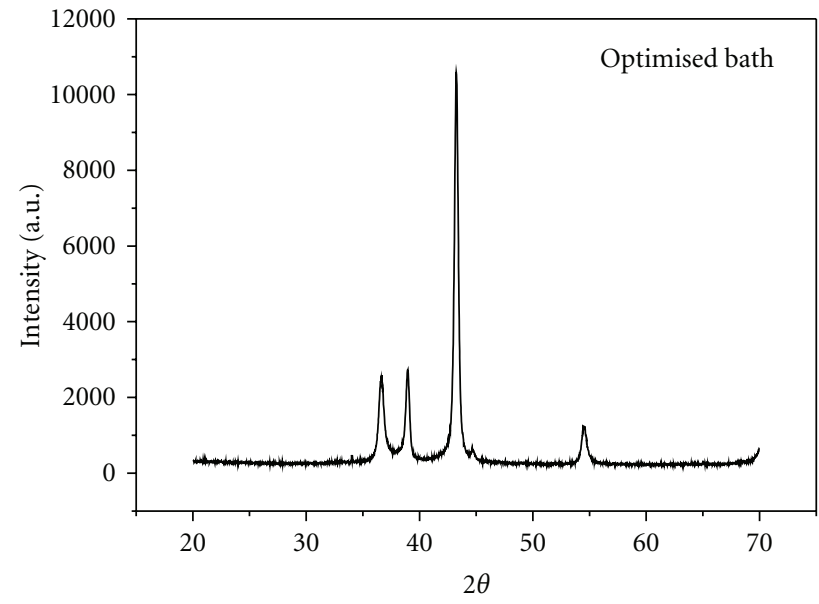

(a)

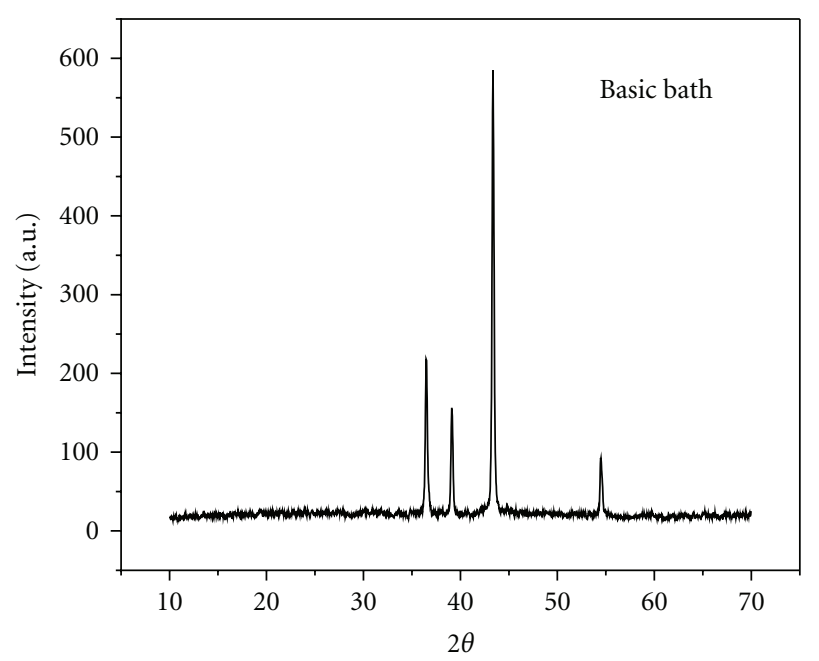

(b)

FIGURE 6: XRD of of optimized and basic bath.

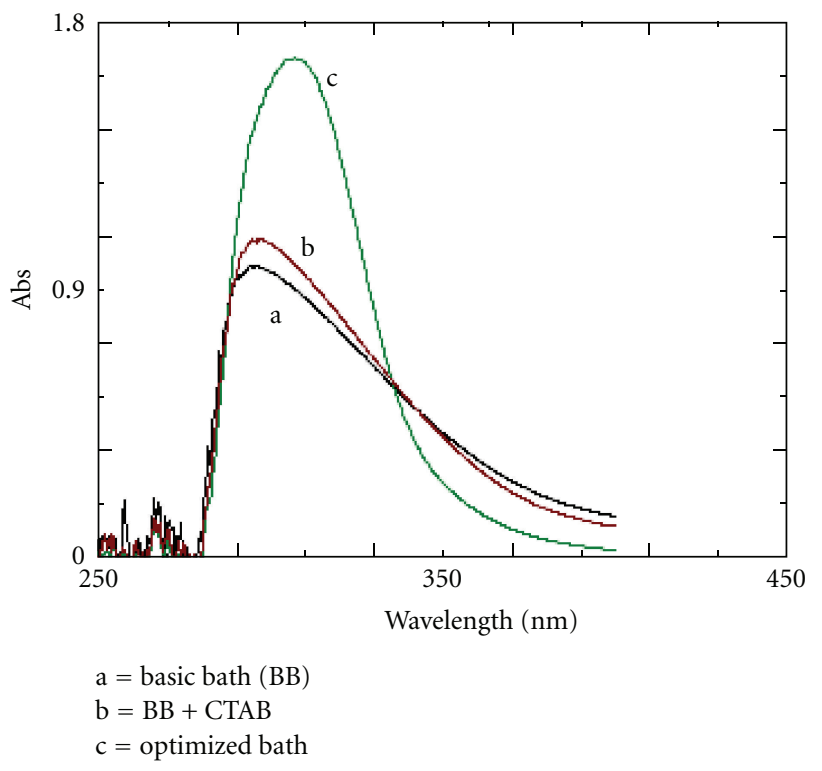

FIGURE 7: UV-visible spectra of Bath solutions.

Pilot Plant Study. The commercial applicability of the developed bath was explored by performing the plating experiments in a vat bath of $25 \mathrm{~L}$ capacity. The bath solution with optimum concentration of bath constituents was prepared. Steel components of different sizes and shapes (plates, rods, nuts, bolts, small pipes, clamps, etc.) were degreased, electrocleaned, and given acid dip followed by water wash. These treated components were rigged by copper wire and connected to the negative terminal of DC source. Electroplating was carried out at different current densities with and without agitation of the bath solution. The components after deposition were removed from the plating vat and subjected to bright dip and passivation. The passivated articles were subjected to corrosion resistance test in a salt spray chamber.
Adhesion of the deposit to the substrate was good as it was confirmed by bend test and heat test methods. The components of irregular shapes plated under stirred and unstirred condition showed no rust at the recesses even after $98 \mathrm{~h}$ of salt spray test. This indicated the ability of the bath to produce uniform deposit on the components of irregular shape.

\section{Conclusions}

The developed bath produced good deposit over the current density range of 0.4 to $7 \mathrm{Adm}^{-2}$. The optimized bath composition and other required parameters are given in Table 2. It requires very small amount of brightener for producing bright plating in wide current density range. The throwing power is reasonably good. The brightener can be easily synthesized. The addition agents are easily soluble in water. The deposit is pore-free and corrosion resistant. The bath could be used in commercial scale.

\section{Acknowledgment}

The authors are grateful to Department of chemistry, Kuvempu University for providing laboratory facilities.

\section{References}

[1] T. Adaniya, M. Omura, K. Matsudo, and H. Naemura, "Development of corrosion-resistant electrogalvanized steel," Plating and Surface Finishing, vol. 68, no. 6, pp. 96-99, 1981.

[2] A. Weymeersch, L. Renard, J. J. Conreur, R. Winand, M. Jorda, and C. Pellet, "High-current-density electroplating of zincnickel and zinc-iron alloys," Plating and Surface Finishing, vol. 73, no. 7, pp. 68-73, 1986.

[3] H. P. Sachin, G. Achary, Y. Arthoba naik, and T. V. Venkatesha, "Polynitroaniline as brightener for zinc-nickel alloy plating from non-cyanide sulphate bath," Bulletin of Materials Science, vol. 30, no. 1, pp. 57-64, 2007. 
[4] A. P. Shears, "Zinc-cobalt deposits from an acid chloride electrolyte," Transactions of the Institute of Metal Finishing, vol. 67, pp. 67-69, 1989.

[5] G. D. Wilcax and D. R. Gabe, "Electrodeposited zinc alloy coatings," Corrosion Science, vol. 35, no. 5-8, pp. 1251-1258, 1993.

[6] K. R. Baldwin, M. J. Robinson, and C. J. E. Smith, "The corrosion resistance of electrodeposited zinc-nickel alloy coatings," Corrosion Science, vol. 35, no. 5-8, pp. 1267-1272, 1993.

[7] K. G. Kariyanna and T. V. Venkatesha, "Electrodeposition of zinc-iron alloy from a sulphate bath," Bulletin of Electrochemistry, vol. 21, no. 12, pp. 547-553, 2005.

[8] Y. Arthoba Naik and T. V. Venkatesha, "A new condensation product for zinc plating from non-cyanide alkaline bath," Bulletin of Materials Science, vol. 28, no. 5, pp. 495-501, 2005. 


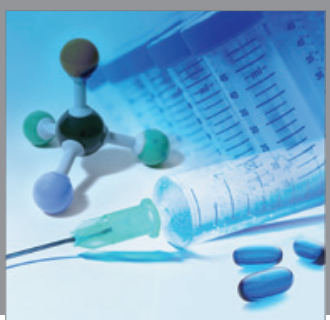

International Journal of

Medicinal Chemistry

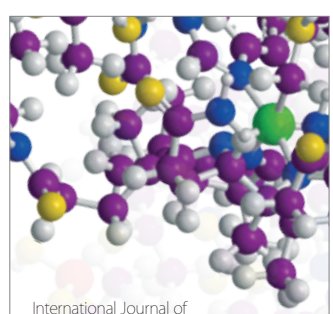

Carbohydrate Chemistry

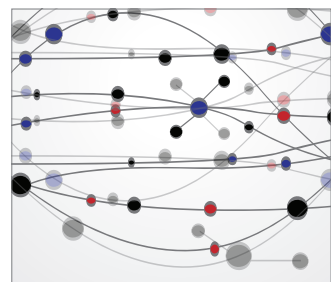

The Scientific World Journal
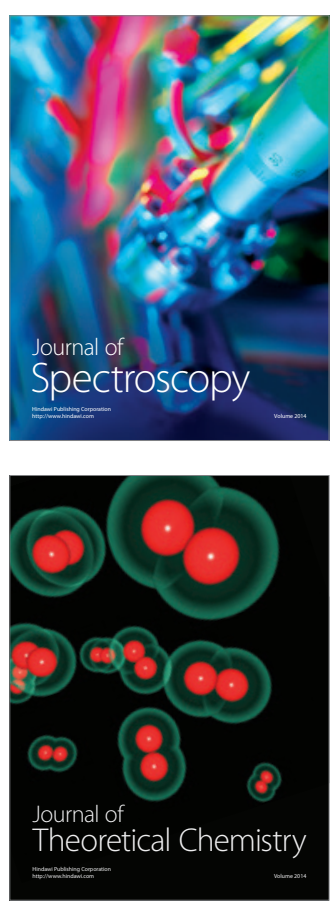
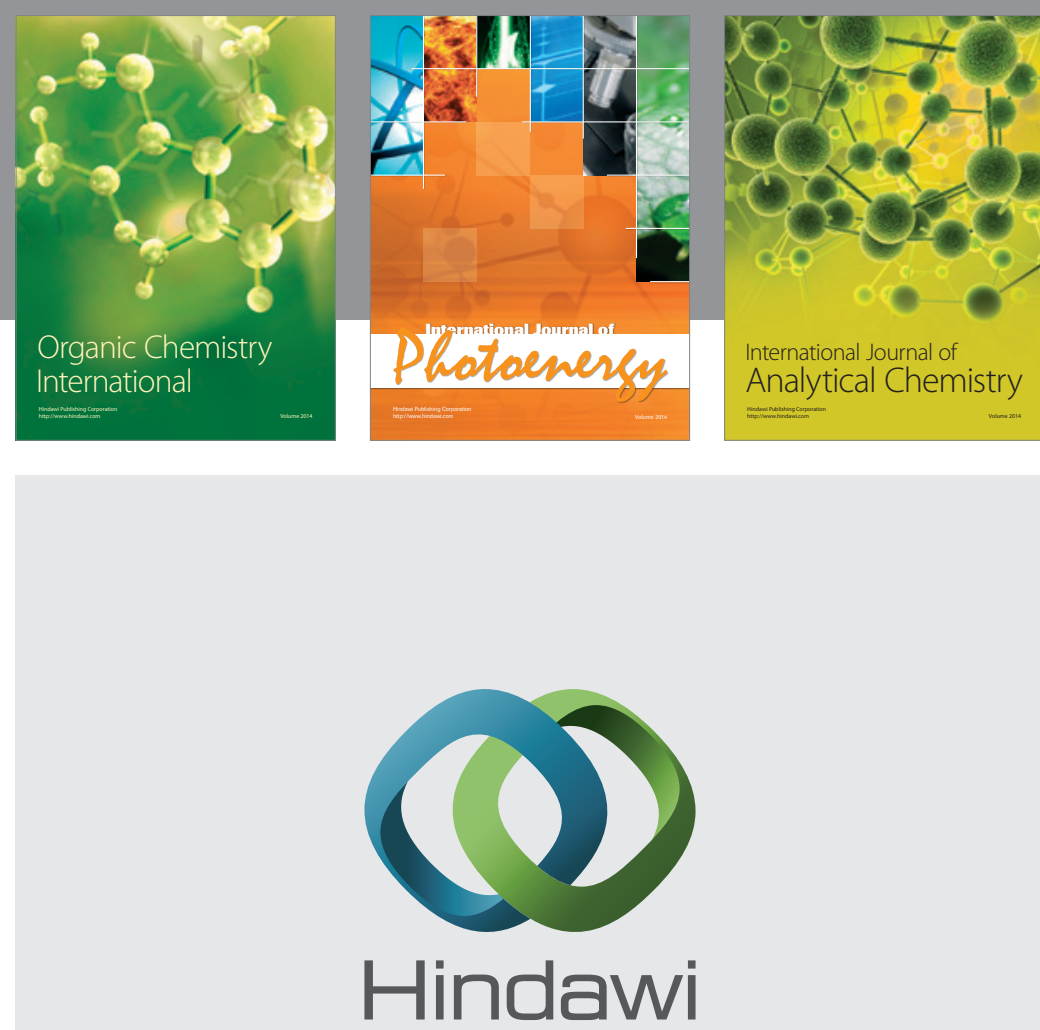

Submit your manuscripts at

http://www.hindawi.com
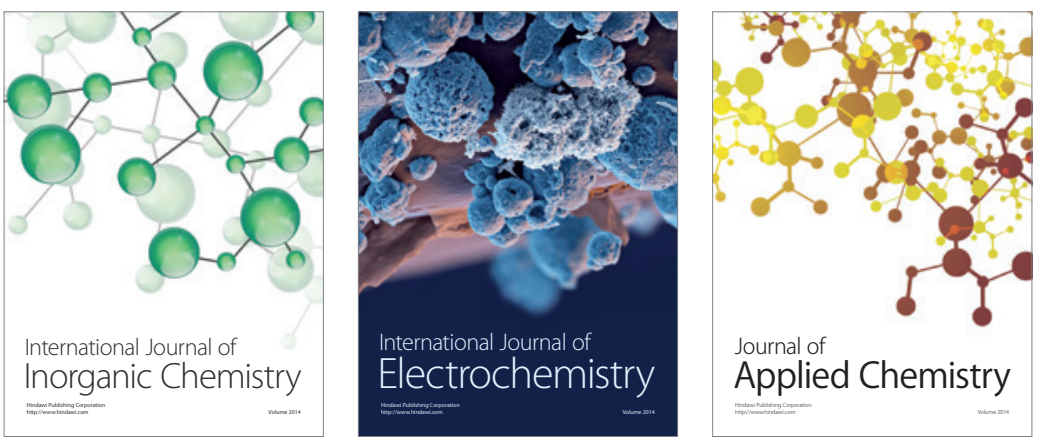

Journal of

Applied Chemistry
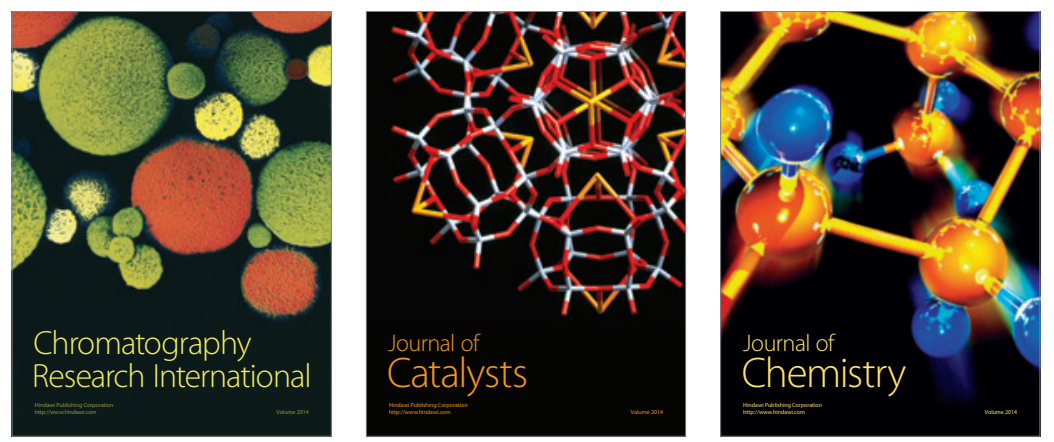
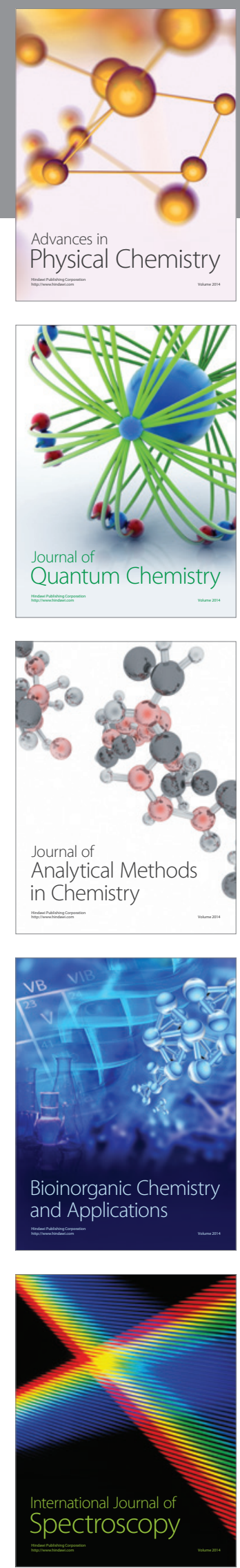